\title{
The Indigenous Ecotourism in Kajang South Sulawesi: Empowerment Issues in The Context of Pa'pasang Ri Kajang
}

\author{
Ega Rusanti ${ }^{*}$, Andi Syathir Sofyan², Syarifuddin ${ }^{3}$, Akramunnas $^{4}$ \\ UIN Alauddin Makassar, Indonesia; egarusanti22@gmail.com \\ 2 UIN Alauddin Makassar, Indonesia; a.syathir@uin-alauddin.ac.id \\ 3 UIN Alauddin Makassar, Indonesia; syarifuddin7890@gmail.com \\ UIN Alauddin Makassar, Indonesia; erossandimahesa@gmail.com \\ * Correspondence: egarusanti22@gmail.com
}

Received: 2021-02-12; Accepted: 2021-06-02; Published: 2021-08-31

\begin{abstract}
The issue of empowerment in indigenous groups has very little attention. This discussion is critical because empowering the indigenous people of Kajang results from a tourism visit that collided with Pa'pasang ri Kajang's value. This article bridges the relationship of ecotourism with the values of the Kajang tribe's beliefs. Second, investigating the issue of empowerment of the Kajang Indigenous community that hinders the development of ecotourism. This article uses ethnographic research methods. The data comes from direct interviews with the Ammatoa indigenous people. The $\mathrm{Pa}^{\prime}$ pasang ri Kajang philosophy plays an essential role in the Kajang community's daily activities; however, various problems arise to develop ecotourism. What the Kajang community should get is feedback from tourist visits. Of course, this article provides knowledge implications about travelling to indigenous peoples' areas and providing input to stakeholders to develop ecotourism.
\end{abstract}

Keywords: Ecotourism; empowerment; indigenous; Kajang.

Abstrak: Isu pemberdayaan dalam kelompok adat sangat minim perhatian. Pembahasan ini sangat penting untuk dikaji, karena permasalahan pemberdayaan pada masyarakat adat kajang akibat dari kunjungan pariwisata terbentur dengan nilai-nilai Pa'pasang ri Kajang. Artikel ini menjembatani hubungan ekopariwisata dengan nilai-nilai kepercayaan suku kajang. kedua, ialah menginvestigasi isu permasalahan pemberdayaan pada masyarakat adat kajang yang menghalangi pengembangan ekopariwisata. Artikel ini menggunakan metode penelitian etnografi. Data bersumber dari wawancara langsung terhadap masyarakat adat Ammatoa. Falsafah Pa'parisang Kajang berperan penting dalam kegiatan sehari-hari masayarakat kajang, akan tetapi timbul berbagai kendala dalam upaya pengembangan ekowisata. Hal yang semestinya didapatkan oleh masyarakat kajang berupa feedback dari kunjuangan wisatawan. Tentunya dengan artikel ini memberikan implikasi pengetahuan tentang berwisata ke daerah masyarakat adat serta memberikan masukan terhadap stakeholder dalam upaya pengembangan ekopariwisata.

Kata Kunci: Ekowisata; Kajang; masyarakat adat; pemberdayaan.

\section{Introduction}

Tourism is one of the fastest-growing industrial sectors and a leading sector in obtaining more significant state revenues (Nazarullail \& Desyanty, 2017). Tourism can revitalize the economy locally by creating employment opportunities in the creative economy (Lembaga Ilmu Pengetahuan Indonesia, 2013). In Indonesia itself, the tourism sector significantly contributed 5.5\% of total Gross Domestic Product (GDP) or equivalent to Rp. 280 Trillion in 2018. This is supported by an increase in local and foreign visitors, with a total of 16.3 million visits. Therefore, economic development in the tourism sector continues to be intensively carried out, considering Indonesia has great potential by utilizing natural beauty and uniqueness of local culture that is used as a tourist attraction (Asmin, 2018). 
One type of tourism that currently needs to be developed and sustainable is nature tourism or ecotourism (Erwin, 2013). Ecotourism is also an idea that is present due to the unrest of the development of tourist areas that usually no longer maintain environmental conservation interests, and the issue of globalization is getting worse. Therefore, ecotourism presents a way of promoting more appreciation of nature through nature's entertainment (Flamin \& Asnaryati, 2013). Some studies showed that ecotourism would be an idea that will be increasingly liked by urban communities and has the potential to continue developing. J.Eagles (2003) revealed that the use of the wild as a means of recovery and self-reflection becomes an increasingly exciting topic of discussion to be studied. While Levy \& Hawkins (2009) found that ecotourism nowadays, in general, is becoming more competitive because it is driven by changes in the contemporary social world that are increasingly complicated so that people tend to want a destination that is more natural and close to natural life to be used as a place to contemplate and relax. Ecotourism is a strategic sector that can be developed and has great potential for environmental conservation, local socio-cultural shifts, and increasing economic income for local communities (Henry, 2015). This concept emphasizes the four pillars of tourism, namely minimizing negative impacts on the environment, responsible development, maintaining local cultural wisdom, and increasing economic income and conservation value (Blamey, 2001).

However, as ecotourism continues, more and more parties are only making this concept a brand in advertising that only adds the label "eco" to the tour package offered without strictly emphasizing the principle of ecotourism (Miller, 2008). Ecotourism developed in a non-careful manner only develops a sustainable tourism sector and triggers more significant losses (Ceylan \& Güven, 2010). Also, the development of ecotourism is often associated with the cultural appeal and social life of local communities that often interfere with the preservation process and harm the local community order due to the influx of tourists (Hall, 2005). Research conducted by R Nash (1970) revealed that the development of ecotourism that is not comprehensive would bring some more severe problems, namely: (1) Failure to provide economic benefits; (2) local communities that are only used as marketing objects and are not included in the process of strategic development and decision making; (3) increased use of alcohol, drugs, energy use; (4) encourage pollution, waste and habitat destruction; (5) the increase of the un-canned population and the process of urbanization that undermines the culture and values of local communities; (6) Land degradation, including forests classified as heritage or customary land. Looking at these problems, the concept of ecotourism can only be built with the participation of the government and local communities (Cajee, 2014). From these efforts came new ideas in the development of ecotourism with community-based (Sinapoy, 2018). Community-based ecotourism is understood as a form of ecotourism that involves local communities as vital control holders (Miller, 2008). This is motivated by the presence of indigenous peoples who are considered to be indigenous owners and ethnic cultures, respect, beliefs, and have a diversity of local ecological circumstances to produce positive reciprocity (Fennell, 2008). Local communities will be better able to consider the advantages and consequences of building their area so that there is expected to be no degradation or change in their community structure (Sinapoy, 2018).

This idea has been widely done and reviewed to see how indigenous peoples encourage the success of more sustainable ecotourism development and consider the possible critical circumstances (Gunter \& Ceddia, 2020). Research conducted by Zeppel, (2003) Australia's development of Aboriginal Ecotourism found that indigenous participation in conservation and decision-making positively affected ecological balance and strengthened socio-cultural values even in a spiritual context. While Figgis P.J (1999), by taking the same research subject that aboriginal people in Australia also found that local communities are present as guarantors of the preservation of natural sustainability, ecocentric philosophy on the environment to foster intrinsic values such as aesthetics and understanding of spiritual values that become an added value in the development of ecotourism. Burns (2005) also found that the natives of Polynesia, Melanesia, and Micronesia, in developing the concept of ecotourism, were able to feel a close emotional bond with their environment. Burns even cited local opinions commenting that "the sky, the oceans, the land and us, we are all one." 
In Indonesia itself, the development of the ecotourism concept with a local community base has not received more attention but continues to be initiated and is expected to strengthen the tourism sector (Asmin, 2018). In Indonesia, various indigenous communities are developing and still known today, such as Dayak tribes in Kalimantan and Kajang in South Sulawesi. Kajang tribe itself has located $250 \mathrm{KM}$ from the East of Makassar City, precisely located in Bulukumba Regency. In terms of ecotourism development, the Kajang traditional area called Amma Toa community becomes unique because it holds full forest/natural maintenance, considered the primary livelihood source (Dassir, 2008). Kajang has 331 rainforests, 17 hectares filled with various types of wildlife and plants that are still very beautiful and guarded through strict rules that bind between the community's social behavior and the sustainability of life wild (Husain \& Kinasih, 2010). The potential development of the ecotourism concept in the Ammatoa area is carried out by prioritizing preferences, perceptions, and motivations between indigenous stakeholders, governments, local communities, and visitors who determine strategies that will generate profits economically and ecologically (Nurkhalis, Arief, \& Sunarminto, 2018).

Ammatoa's indigenous people hold hereditary teachings known as "Pasang." The Pasang contains a series of old devices that become the local people's philosophy of life there. One of the pasang mentions that the world is a creation of Turie'A'ra'na (the Creator) and its contents that need to be maintained balance, mostly the forest as a life source (Syukur et al., 2015). Therefore, the community strives to preserve nature by instilling high moral values to create a harmonious life between nature and man (Husain \& Kinasih, 2010). Not only the traditional tourism that Although some basic principles in the leading pasang related to the concept of balance of the afterlife and modesty in the view of the Ammatoa Kajang Community are not in line with the concept of Islam, the intrinsic values and moral spirit/akhlaq and wisdom still need to be appreciated that the implementation of the points contained in the Pasang in the form of awareness of the importance of balance between humans and the design of his work on the environment (Heryanti, 2008). Therefore, this study will discuss empowerment in the context of the traditional values of pa'pasang ri kajang, which are the philosophy of life of the Kajang community, including in terms of environmental protection. This discussion has never been addressed in various previous research articles. Most researchers only reveal the meaning of pa'pasang ri Kajang but do not see this potential as a strength in building Kajang ecotourism through the concept of empowering indigenous peoples. The beliefs and values of life held firmly by the indigenous people in Kajang should be a positive lesson and an essential consideration in initiating a more integrated and comprehensive ecotourism development. in the framework of empowering ecotourism based on local communities by prioritizing five dimensions of empowerment, namely economic empowerment, social empowerment, political empowerment, psychological empowerment, and environmental empowerment (Islam \& Carlsen, 2016).

This research has two objectives: first, understanding the relationship of ecotourism with Kajang tribe beliefs. The second is to investigate the issue of empowerment in Kajang indigenous peoples that hinder ecotourism development. Both objectives will contribute to the practice of providing tourism development inputs to the Bulukumba district government as well as local tourism stakeholders. This research also contributes scientifically, where the results of this research will provide insights to the audience/readers about how indigenous peoples are migrating in terms of tourism that gives fair results to them. In this study, the authors used ethnographic research methods. Ethnography is one qualitative research method that seeks to explore a community culture (Windiani \& Nurul, 2016).

Using ethnographic methods, researchers must release personal assumptions and assumptions about a group of people to effectively learn something about them (Sugiyanto \& Winardi, 2019). Besides, this study uses data sourced from direct interviews with the Ammatoa indigenous people, which lasted for three weeks. The length of time of the research was due to the limited access allowed in the Kajang Amma Toa area, so it took quite a long time to observe and get accurate information about the lives of local communities and the ecotourism development strategy that will be carried out. The determination of informants was carried out by looking at traditional leaders and the Kajang Customary community through the Kajang Luar community intermediary in assisting the interview 
process, which was often constrained in terms of language to communicate with informants. Researchers used structured interview guidelines that covered empowerment issues that included economic, social, political, psychological, and environmental empowerment. In analyzing the data, researchers used data analysis techniques developed by Milles and Huberman (1994). The first step, editing by giving identity to the research instrument that has been answered. After that, the coding stage. This means that the edited data is provided an identity to have a specific meaning at the time of analysis (Miles \& Huberman, 1994).

\section{Kajang and the Indigenous Ammatoa Community}

Kajang tribe is one of Indonesia's tribes that still maintains local wisdom and cultural values in the tribe (Rusdiansyah, 2019). Kajang tribe itself has located $250 \mathrm{KM}$ from the East of Makassar City, precisely located in Bulukumba Regency (Usbar, Mahbub, \& Makkarennu, 2019). Kajang area is divided into eight villages and six hamlets. However, keep in mind, Kajang is divided into two geographically, namely Kajang Dalam (Kajang tribe, they are called "tau Kajang" or indigenous people of Ammatoa) and outer Kajang (people who live around relatively modern Kajang tribe, they are called "people who live around relatively modern Kajang tribe, they are called "tau lembang." The Kajang people live in Tana Toa Village, Bulukumba Regency, South Sulawesi Province. Geographically, the area is a bumpy, hilly area. You can see the Lompobattang-Bawakaraeng mountain range and Bantaeng Valley in the West from some village regions. Besides, there is also Bone Bay, with a Nine islands cluster (Rusdiansyah, 2019).

The Kajang tribe, better known as Ammatoa Custom, has long inhabited Tana Toa, Bulukumba area, South Sulawesi (Disnawati, 2013). The Kajang tribe is one of the classic indigenous peoples. They live in remote areas and still maintain traditional values by maintaining Ammatoa figures or indigenous stakeholders' sacredness. Kajang area is also famous for its customary law, which is very thick and still valid today (Sharon \& Paranoan, 2020). They distance themselves from everything related to modernization, economic activities, and the Government of Bulukumba Regency. People in Kajang traditional areas become unique because they fully maintain forest/nature and life philosophy (Dassir, 2008). From centuries past to the present, they have lived and survived in the traditional and unpretentious way of life (Kamase-masea). They believe that such a way of life was once done and ordered by their ancestors (Boheta) to be carried out by the next generation, so as tradition hereditary can be seen in the Ammatoa Indigenous Area at this time (Hijjang, 2014).

A distinctive feature of the Kajang Tribe is the clothing worn by the Kajang Tribe. The Kajang tribe always wears black clothes and does not wear footwear (Hijjang, 2014). If there are tourists who want to visit, the clothes must wear black clothes (see figure 1). Because according to the Kajang Tribe, black color has the meaning of equality, unity in all things, and simplicity. The black color also shows strength and degree in the eyes of the owner of the universe. The similarities in this color also address environmental conditions, especially forest sustainability, because it is the source of life. (Abdullah, Cangara, \& Tang, 2014). In Kajang tribal communities, technological tools that have proliferated today are not found. The community still adheres to existing norms in the Kajang tribe, such as not allowing electronic devices or technology that is now a necessity of modern society, such as mobile phones and the Kajang tribe's location. This causes public communication to be limited to the direct word of mouth communication (Rusdiansyah, 2019).

Ammatoa Indigenous Peoples with local wisdom known as Pasang is the umbrella of customary law on forest conservation. Ammatoa Indigenous Peoples in managing forest resources are inseparable from their belief in tidal teachings. Ammatoa Indigenous Peoples understand that God's world (Turiek Arakna) and its contents must be balanced, mostly the forest. Therefore, the forest must be well maintained, receive special treatment for its inhabitants, and not damage it (Wijaya, 2018). 


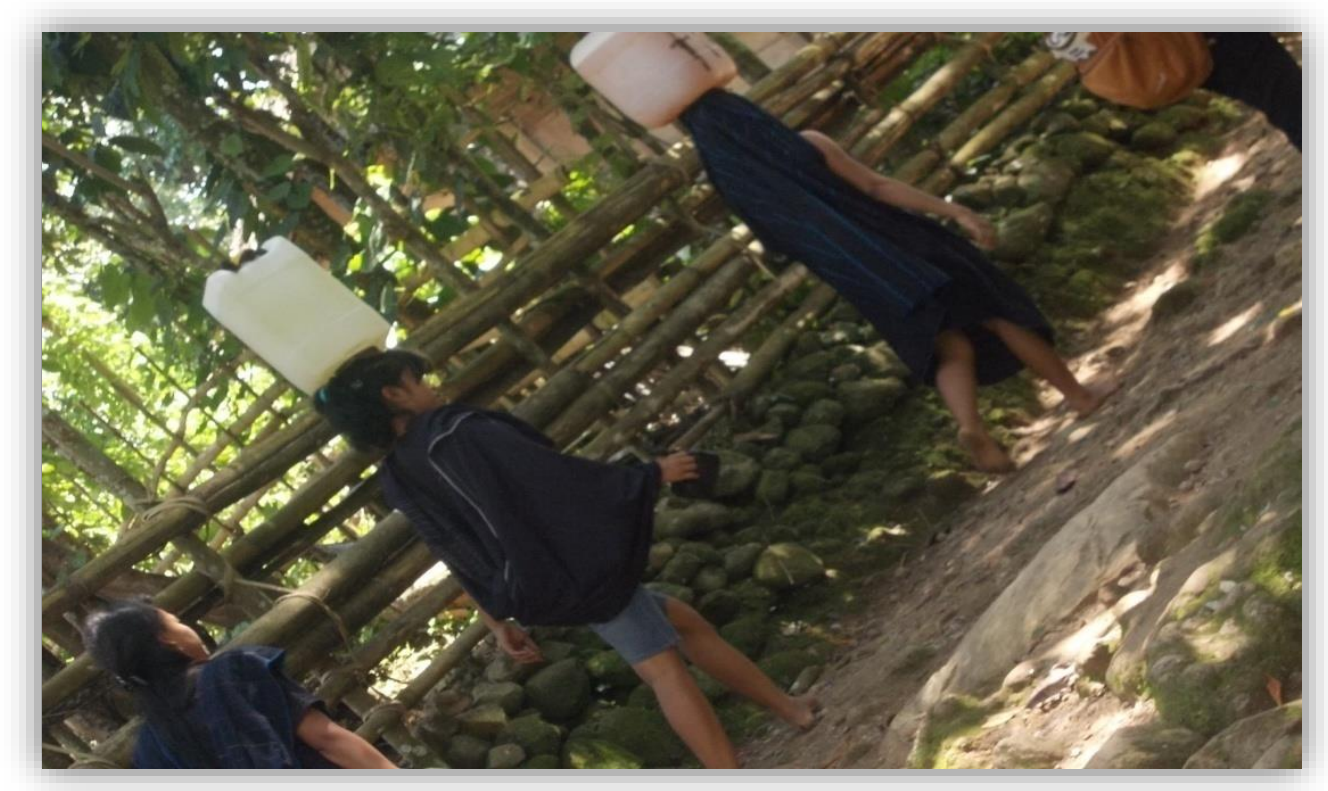

Figure 1 Indigenous People of Kajang

\section{Pa'pasang ri Kajang in Ecotourism Care Efforts}

Kajang traditional people interact with the surrounding environment, adhere to or rely on Pasang ri Kajang (message in Kajang) (Abdullah et al., 2014). Pasang means "message." However, in the Ammatoa community sense, Pasang contains more than just a message. It is more of a sacred trust. It is proven that Pasang must be obeyed, obeyed, and implemented. If not implemented, it will result in the emergence of undesirable things, such as damage to the balance of social and ecological systems (Syukur et al., 2015). This condition makes Kajang unique and distinctive to learning for other communities in South Sulawesi, even in Indonesia, in building fair and sustainable forestry. Indicators of sustainable forests in Kajang are inseparable from compliance and respect for customary laws outlined in Pasang ri Kajang (Badewi, 2018).

Install as information from ancestors, which is passed down orally from generation to generation (oral tradition), giving knowledge to the public about the nature of life and life, both in the world and in the future. Therefore, Pasang covers things about the way they live in society and culture. Pasang contains meanings: mandates, fatwas, advice, guidance, warnings, and reminders for the community. Pasang ri Kajang is a fundamental knowledge of life aspects, both worldly and ukhrawi, including myths, legends, and genealogies. For Ammatoa people, Pasang is a knowledge system that recognizes the community and outside communities (Hijang, 2005). Thus Pasang ri Kajang is widely found also in other cultures with different languages, but Makana and the same goal is to bequeath strong cultural values in the next generation (Wijaya, 2018).

The principle of life in "Pasang Ri Kajang" turns out to be one reason for the continued forest in the Kajang customary area. Simple life principles such as Balla's situju-tuju or roughing house result in the use of wood more efficiently, making the forest a multi-functional place and having a crucial and sacral role and making the forest preserved sustainably although it can be utilized (see figure 2). Evidence of this can be seen today in the Kajang traditional area, the trees thrive without exploitation, and although there are fallen trees by themselves, they should not be taken by the community (Badewi, 2018). 


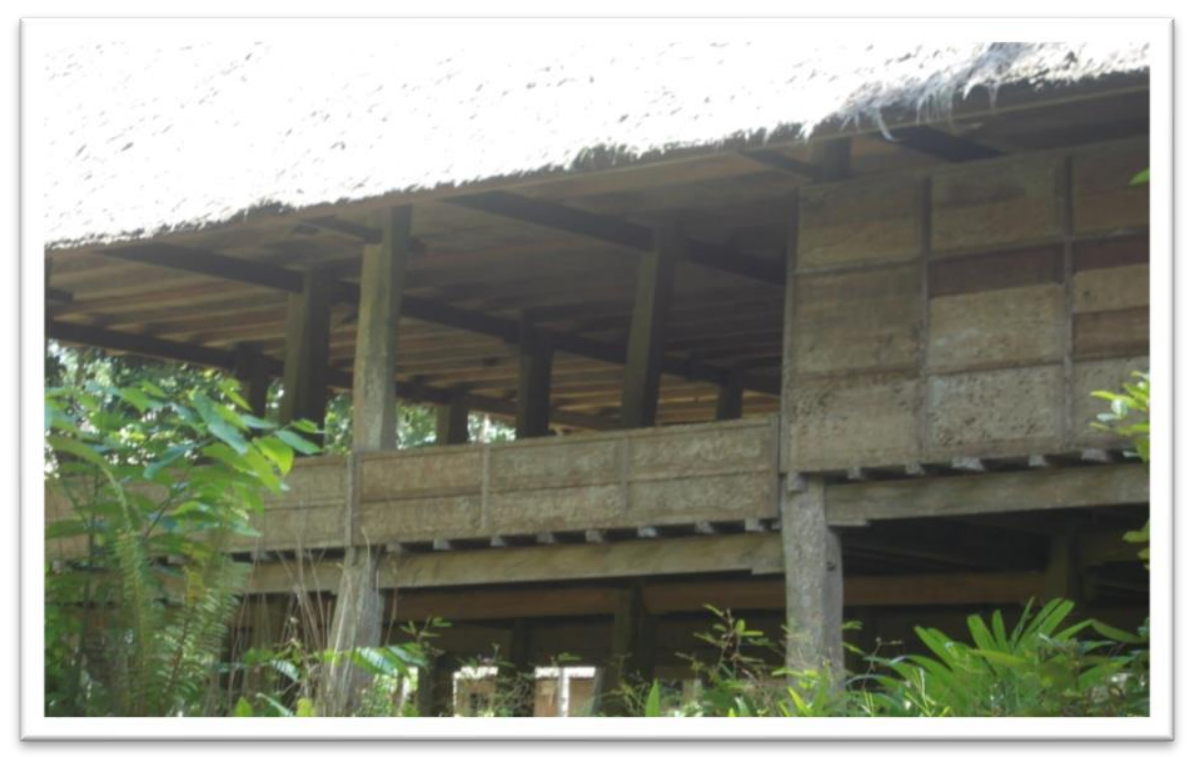

Figure 2 Kajang's communities house

Ammatoa indigenous peoples understand that the world created by Tu Rie $A^{\prime} r a^{\prime} n a$ and its contents must be maintained in balance, mostly the forest. Therefore the forest must be well maintained and receive special treatment for its inhabitants and not damage it. One of the Pasang reads "Anjo boronga anre nakkulle nipanraki. Punna nipanraki boronga, nupanraki kalennu" means the forest should not be damaged. If you break it, then it's the same as you are ruining yourself. Another Pasang reads: "Anjo natahang ri boronga karana pasang. Rettopi tanayya rettoi ada" means that the forest can be sustainable because customs guard it. If the earth is destroyed, then the custom is destroyed (Syarif, 2018).

As a knot of the community's whole way of life, it is regulated how communities treat their forests of the 120 articles or things in Pasang almost all related to the problem of environmental management procedures, especially those related to the preservation of customary forests. Of the 120 articles, 83 articles contain general rules, 18 articles containing pantun and art, and 19 articles containing environmental management systems, especially customary forests (Husain \& Kinasih, 2010). The several Pasang related to environmental preservation are as table 1.

Table 1 Pa'pasang ri Kajang about Environment

\begin{tabular}{cll}
\hline No & \multicolumn{1}{c}{ Pasang } & \multicolumn{1}{c}{ The meaning } \\
\hline 1 & $\begin{array}{l}\text { Jagai linoa lollongbonena kammayya } \\
\text { tompa langika siagang rupa taua siagang } \\
\text { boronga }\end{array}$ & $\begin{array}{l}\text { Preserve the earth and its contents, as well as the } \\
\text { heavens, people, and forests }\end{array}$ \\
\hline 2 & $\begin{array}{l}\text { Nikasipalliangngi } \\
\text { manrakia borong }\end{array}$ & Forbidden to be challenged to damage the forest \\
\hline 3 & $\begin{array}{l}\text { Anjo boronga iya kontaki bosiya nasaba } \\
\text { konre mae pangairangnga iaminjo boronga } \\
\text { nikua pangairang }\end{array}$ & $\begin{array}{l}\text { The forest invites rain because there is no watering } \\
\text { here, so it serves as water because it brings rain. }\end{array}$ \\
& $\begin{array}{l}\text { Punna nitabbangngi kajua riborongnga, } \\
\text { nunipappi rangnga }\end{array}$ & $\begin{array}{l}\text { If the wood in the forest is cut down, the rain will } \\
\text { decrease, and the springs will disappear (dry up). }\end{array}$ \\
\hline
\end{tabular}




\begin{tabular}{cll}
\hline 5 & $\begin{array}{l}\text { Angngurangi basi patane timbusu. } \\
\text { Nibicara pasang ri tau Ma'riolo Narie' } \\
\text { kaloro battu riborongnga, narie' timbusu } \\
\text { battu rijakua na battu ri kalelengnga }\end{array}$ & $\begin{array}{l}\text { That is the message of the former. } \\
\text { The existence of rivers derived from forests, the } \\
\text { presence of springs derived from trees and liana }\end{array}$ \\
\hline 6 & $\begin{array}{l}\text { Boronga pangallui nitallasi, erea batturi } \\
\text { kaloro lupayya }\end{array}$ & $\begin{array}{l}\text { Forests need to be preserved because water comes } \\
\text { from small rivers }\end{array}$ \\
\hline 7 & $\begin{array}{l}\text { Iyamintu akkiyo bosi anggenna erea } \\
\text { nipake a'lamung pare, ba'do appa'rie' } \\
\text { timbusia Anjo }\end{array}$ & $\begin{array}{l}\text { He (forest) brings rain so that it may be used to } \\
\text { grow rice, corn, and water. }\end{array}$ \\
\hline 8 & $\begin{array}{l}\text { Tugasa'na Ammatoa nolarangngi } \\
\text { annabbang kaju ri borongnga }\end{array}$ & $\begin{array}{l}\text { The task of an Ammatoa is to prohibit logging in the } \\
\text { forest }\end{array}$ \\
\hline $9 \begin{array}{l}\text { Iyaminjo nikua ada'tana Iyaminjo } \\
\text { boronga kunne pusaka Talakullei } \\
\text { nisambei kajua, iyato' minjo kaju timboa }\end{array}$ & $\begin{array}{l}\text { Thus the law that applies here the forest is our } \\
\text { inheritance }\end{array}$ \\
\hline $\begin{array}{l}\text { Talakullei nitambai nanikurangi borong } \\
\text { karama, nilarangngi tauwa a'lamung- } \\
\text { lamung riborongnga, nasaba se're hattu } \\
\text { larie' tau angngakui bate lamunna }\end{array}$ & $\begin{array}{l}\text { It is not allowed to change the type of wood in the } \\
\text { customary forest, that is, all wood that grows } \\
\text { naturally can not be added and reduced, } \\
\text { prohibited planting activities in customary } \\
\text { forests, because one time there will appear } \\
\text { recognition of plant property rights }\end{array}$ \\
\hline
\end{tabular}

Source: (Dassir, 2008)

The first Pasang confirms that nature is divided into three continents, namely the upper continent, namely boting langi' (sky), the middle continent (where living things include humans) is called lino, and the lower continent is called paratihi (ocean), is a unity that is bound to each other and forms a system called the world. This first Pasang is the first law that as a human being must preserve nature and its contents because human life is inseparable from the environment in which it lives. The whole earth is His creation, and man is His glorious creation responsible for preserving it (Dassir, 2008).

The second pasang insists not to take/damage the forest (wood, rattan, and animals), exploit the forest excessively because it can cause flooding, dry water sources, and damage ecosystems' balance. So floods, loss of water sources (due to deforestation), or reduced soil fertility (as a result of land intensification efforts) are the result of greedy human acts "tubakka teka'na" or not kamase-mase (simple) (Utaya \& Susilo, 2015).

The third and fourth pasang can be concluded that the community will not cut down the forest because every cut down of wood will reduce the spring source. They have no river flow, so their reliance is only on the forest that produces the springs. Continuous logging will only eliminate the source of the springs. This is a hereditary message passed down to answer why trees in the forest cannot be cut down. Therefore, their actions are very beneficial for sustainable and denser forests. Through this Pasang, cultural values teach the kajang community to be disciplined and obey the rules that impact human good and forest sustainability (Wijaya, 2018). The fifth to seventh pasang explain forests' role in the availability of springs that benefit people's lives and livelihoods as farmers and their farmland. A correct understanding of the role of forests for water availability will preserve the ammatoa community. They were keeping forests sustainable means keeping themselves. Breaking the rules would destroy their resolve against the rules they had agreed to (Badewi, 2018).

The eighth and ninth pasang emphasize the importance of forests for Ammatoa Indigenous peoples because forests are considered heirlooms, so that the responsibility for preserving forests is held by 
Ammatoa (indigenous leaders). From the expression, Pasang ri Kajang above, the power entrusted to the Government's control is not arbitrary, but the power must be maintained to realize society's welfare. The trustees' government control attitude is very decisive in creating a harmony of the relationship between nature and human life. (Utaya \& Susilo, 2015).

The last Pasang confirms that no logging or planting should be carried out in the customary forest (Grosir Karama'). The trees inside are allowed to grow and experience natural succession. Thus, no one will admit ownership of the forest personally. It also means that everything standard from the Government or customs should not be disturbed because it is a provision that must be obeyed. A person's ownership of an item or position should not be disturbed by others because it is his right (Dassir, 2008).

As part of an ever-moving and dynamic society, there is no guarantee that Kajang indigenous peoples will always obey pasang rules. This is fully realized by the indigenous stakeholders so that there are also several sanctions and orders, and prohibitions. The violations are classified into three categories, namely heavy, medium, and light. Serious violations will be subject to a poko' ba'bala (base whip) penalty, equivalent to a fine of 12 real or 24 ohang (VOC rupiah). Currently, the fine is equivalent to Rp1.200.000,00 plus a shroud for Muslims as much as 24 elbows or about 12 meters. For medium violations is the penalty is tangnga ba'bala (middle whip) or equivalent to a fine of 8 real or 16 ohang or comparable to Rp800.000,- As for minor violations imposed cappa ba'bala penalty (tip of whip) or equivalent to 4 real or eight ohang or comparable to Rp400.000.- (Husain \& Kinasih, 2010).

Based on these pasang every visitor who enters the traditional area is emphasized to take off their footwear. Visitors who come are required to follow the applicable customary rules. No modern vehicles; visitors can only ride horses or walk. Besides, it is also recommended to wear black clothing. If visitors do not wear black clothes, next to the gate are provided traditional clothes that visitors can rent for $\mathrm{Rp} 100,000$ for three traditional clothing sheets.

\section{Indigenous People Ammatoa Empowerment in Encouraging Ecotourism in Kajang}

The need to implement strategies for economic development to be implemented and ensure nature conservation and development for local communities has led to the development of biosphere reserves, where communities have the right to use biological resources following designated spatial zones (Coria \& Calfucura, 2012). Indigenous peoples can make the ecotourism sector as an effort to improve their standard of living because of various opportunities that can be utilized(Johnston, 2000). Therefore, various development efforts are necessary to provide a large space to indigenous peoples and make them the main focus in vital policy-making, especially those directly related to nature conservation (Jennings, 2017).

Various potentials of this attraction become objects in developing ecotourism. However, the effort to develop the role of indigenous peoples is still minimal. Simultaneously, local communities will be better able to consider the advantages and consequences of building their area so that there is expected to be no degradation or change in their community structure (Sinapoy, 2018). Scheyvens (2002) adapted the empowerment framework to measure empowerment from psychological, social, economic, political, and environmental dimensions in ecotourism through indigenous peoples. Economic Empowerment, where tourism can provide sustainable benefits for local communities. With empowerment, psychological empowerment indirectly through the introduction of customs, culture, and natural and human resources began to be known by the outside world. Social empowerment improves people's social life through efforts made by each family and individual who support tourism development. All community groups ' desires and needs indicate political empowerment, every structure, and the layer of community politics. Environment empowerment, with indicators of understanding the balance of nature by regulating waste disposal, raises awareness of conservation needs (Ramos \& Prideaux, 2014).

\section{Economic Empowerment}


Ecotourism will be successful and beneficial for local communities both economically, socially, and environmentally if it can combine the natural potential of a protected forest area, the social aspects of the local community, and the participation of the community both as actors and organizers of ecotourism activities (Hafid, 2013). For ammatoa indigenous peoples, forests are an inseparable part of their survival. For them, forests are for daily needs and maintain the balance of ecosystems and ritual interests. The influence of modernization that emphasizes wood as a commodity of high economic value is also understood, but indigenous peoples' behavior is still served by actions that concern the environment (Disnawati, 2013). Besides, basic livelihoods are agriculture and plantations with tinang (edible crops), especially rice (pare) and corn (batara). For economical crops around the settlement is coffee, cashews, cocoa, langsat, durian, rambutan, cloves, pepper, and nuts. Side crops include cassava, sweet potato, taro (Ikbal, 2018).

Several forms of development in terms of infrastructure are not allowed in the customary legal area (ilalang embayya), such as telecommunication infrastructure (telephone and internet), electricity, and asphalt road infrastructure. Indigenous stakeholders and local governments have agreed to maintain the culture of ammatoa Kajang indigenous peoples not to accept modernization in indigenous areas, including electricity, telecommunications, and paved roads (Nurkhalis et al., 2018). The economic benefits carried out by Kajang indigenous peoples towards tourism activities in their area are innumerable. Unlike other tourist areas that generally provide entrance ticket prices and souvenirs. Ammatoa indigenous leaders give freedom to anyone who wants to know Kajang local people's lives by paying attention and obeying the established rules such as not using footwear, wearing black clothes, and not doing the deed scope of the customary area. Local people also do not peddle typical souvenirs Kajang; there are only one traditional clothes rental stall located close to the customary area's entrance with a price of Rp.100,000 for three pasang of traditional clothes. This is done to show the nature of local people's straightforward and evenly distributed lives, nothing conspicuous and coexistence or the kamase-kamasean.

Even in indigenous areas, economic activities and benefits do not have much impact on local communities. However, Tana Toa Kajang's ecotourism positively influences the economy of the communities around Kajang Dalam. Various routine rituals unique in the Adat area, such as the ceremony of reject bala nganre sassan, or the ritual of asking for sustenance and safety known as adingingi become the favorite momentum of visitors to travel in this area because they can interact and witness this annual traditional procession. Therefore, local communities utilize opportunities outside the customary area to provide tourism facilities such as homestays and typical Kajang Adat Kajang snacks during the traditional procession. Seeing this, Indigenous peoples can participate economically by utilizing similar circumstances. For example, original woven fabrics and various trinkets in rituals such as hats and clothes made by Kajang Indigenous women can be sold directly or intermediaries from people outside the adat area to be economically valuable.

\section{Social Empowerment}

Social empowerment is related to society's integration through cooperation between individuals and groups in building a successful business. Some of the results obtained are used for development and or community development from initiatives and derived from local people's philosophy of life in developing their territory as an ecotourism destination(Sambou, Riniwati, \& Fanani, 2019). Kajang indigenous communities are easily known for showing characteristics that distinguish them from other social groups. The specifications are not only found in the attributes worn such as; clothes, pants that almost touch the knees, sarongs, destar, or headbands worn for men, all black (Badewi, 2018). Kajang people believe that the land where they live is the oldest land or land first created by God, so their place is named Tanah Toa Village, which means the oldest land (Embas, 2017). Kajang Dalam people's life is colored by various cultural histories that became the heritage of their ancestors and had many traditional ritual activities that become Kajang people's custom (Husain \& Kinasih, 2010). Besides, the strong cultural identity is caused by the keeping of the Pasang in the reality of their daily lives. Ammatoa 
society can maintain social order through internalization and institutionalization of institutionalized socio-cultural values in the form of pasang (Wijaya, 2018).

Although many tourists and researchers from various regions have visited, Kajang indigenous peoples still uphold the customary rules that are binding and not affected by the outside world's development. Similarly, with the use of language and information, Indigenous peoples cannot provide information outside the permission and submission given by the chairman of Ammatoa custom. Visitors who wish to explore information about Kajang are advised to speak to Ammatoa using konjo's local language either directly or through translators who generally come from people living around the Kajang area. Also, visitors are not allowed indiscriminately to record and photograph and use technology devices across the place. Some places would not usually be allowed to be portraited, such as the main forest area and some sacred wells. If visitors commit violations, they will be reprimanded by the local community using both spoken language and body language. Such strikes are usually done by trying not to offend and frighten visitors because indigenous peoples are so appreciative of visiting guests but, on the one hand, also do not want to see the visitors make mistakes and will lead to woe.

Therefore, to encourage ecotourism in this region and see a growing number of communities from visitors to researchers both at home and abroad interested in Ammatoa. As the regulator and facilitator in maintaining the sustainability of Kajang traditional life, the local Government is considered necessary to provide facilities and mediate tour guides who are structurally and trained with various mastery of the situation and language prevailing within the ammatoa area. This will help visitors if they want to know more about local people's lives and avoid pamali-pamali and still comply with the applicable rules because there will be people who understand accompanying and reminding.

\section{Psychology Empowerment}

Pasang is a value system that becomes the highest guideline for Kajang indigenous communities in conceptualizing the most valuable things in life, both world-oriented and hereafter (Disnawati, 2013). Pasang gave birth to Kajang indigenous people's mental attitude towards supernatural forces outside him and the procedures of treating him and forming beliefs in all these things. Based on the Pasang, Kajang indigenous peoples can build harmonious relationships between individuals, indigenous leaders, nature, and God. The Kajang community also interacts more with fellow Kajang people, which causes the Kajang community to experience obstacles when interacting socially with different ethnic participants. The Kajang community's communication process sounds typical and fewer obstacles because the Kajang community using the same language, namely the Konjo language (Sudirman, 2017).

The lives of Kajang Indigenous peoples are very closed to the outside world. In and out, visitors do not shake the principle of the life of a society that is not enslaved by technology's sophistication but still lives simply with everything. Even so, the Kajang people did not immediately reject any visit in their customary region. On the contrary, the local community still accepts all respect and still maintains visitors' safety and comfort. Visitors are also allowed to see all local activities, such as in the fields and daily activities at home, with a record of maintaining customs and complying with applicable rules. Even the Kajang traditional house pattern that puts the kitchen's position at the very front of the house is a natural form of indigenous people's respect for their guests. If the house's kitchen is seen billowing smoke, that means that the homeowner is serving food, so that every guest who enters at that time must be served all the food that is being made.

However, some things usually become the concern of Indigenous peoples with visitors who usually behave recklessly and ignore rules such as littering, uprooting, spying on wood or plants, and killing animals or insects to sometimes laugh at things considered sacred to the surrounding population. This is usually the case because there is no direction before entering the customary area and written rules displayed for visitors to read. Therefore, as mentioned above, the presence of a guide or visitor companion will help avoid these things.

\section{Political Empowerment}


Ammatoa Kajang Customary Forest Area is a forest within the Indigenous Peoples of Ammatoa Kajang Bulukumba Regency with the primary function of protection following the Decree of the Minister of Environment Forestry number SK.6746/MENLHK-PSKL/KUM.1/12/2016. Ammatoa Kajang Indigenous Forest has ecological and cultural potential in the form of non-timber forest products, environmental services, diversity of flora and fauna, local wisdom, and socio-cultural that can be an object of ecotourism development (Husain \& Kinasih, 2010). The Kajang community still upholds its noble values and customary laws, making the nature and customary forests of Kajang maintained; the local Government of Bulukumba Regency, South Sulawesi, took the initiative to protect it by drafting local regulations. This regulation on the Confirmation, Recognition, and Protection of Indigenous Peoples of Ammatoa Kajang Is made because of their internal factors, where indigenous institutions need to be established to not disappear in the future. The process of local recognition of Kajang indigenous peoples as a means of government campaign under legislation recognition of indigenous peoples' protection is being processed in Bulukumba. The meaning of various parties, especially the Government, towards the region and evaluation for the improvement of the management of ammatoa Kajang custom is considered necessary to the indigenous area of Ammatoa Kajang by the parties- in assessing the feasibility of an area (Nurkhalis et al., 2018).

However, the fulfilment of Kajang Indigenous Peoples' rights has not been fully realized by the Government. This is evidenced by discrimination against Kajang Indigenous Peoples in the management and utilization of Customary Forests carried out by the Government. In this case, PT. Longsum, as a company that manages and utilizes the Riallaa Indigenous Forest owned by the Kajang Indigenous Peoples law, is proof of the Government's discrimination against the indigenous people. With the management and utilization of this Customary Forest by the Government, the Kajang Indigenous Peoples cannot take advantage of their customary forests and there are four thousand Indigenous Peoples who do not have a place to live(Muhdar \& Jasmaniar, 2006)

Ammatoa Kajang indigenous ecotourism's sustainable development can be obtained by assessing the parties' perceptions, motivations, preferences, and participation reviewed from various related indicators. Perception of the availability and condition of infrastructure and facilities in the indigenous area of Ammatoa Kajang is considered moderate by it needs to be made improvements to some infrastructures and facilities so that its availability and conditions can support the comfort of visitors/tourists. The economic motivational assessment shows a relatively high score indicating that stakeholders agreed to develop ecotourism. The parties' preference put a relatively high willingness towards ecotourism in Kajang so that the relevant parties agreed to develop sites and destinations and empowerment of local communities. Stakeholders who have influence and interest in the indigenous forests of Ammatoa Kajang need to hold a joint meeting to formulate a useful ecotourism development model that can be applied to indigenous areas. Besides, the parties' preferences need to be considered related to the development of sites and destinations in indigenous areas concerning the culture that is still preserved (Nurkhalis et al., 2018).

\section{Environmental Empowerment}

Customary law has the potential to manage and protect forests sustainably. The management of forest resources by ammatoa indigenous peoples in Kajang is based on Pasang ri Kajang's teachings, which serve to maintain and protect forest areas. Forest management must be tailored to the forest's potential and the local community's socio-cultural conditions (Syarif, 2018). Ammatoa indigenous peoples adhere to principles in managing forests, such as the principle of respect for nature, the principle of responsibility to nature, the principle of cosmic solidarity, the principle of compassion and care for nature, the principle of the simple life, the principle of living in harmony with nature and the principle of justice.

The forest (local language: borong) consists of three kinds. First, hutan panai, where all indigenous peoples can live and work there and can also cut down for their purposes, but the small wood that will grow must be left and maintained. Second, ade forest, where people can take wood but must be knowledgeable of custom and if without customary knowledge, it will be punished. Third, karrasa 
forest can not be taken at all, even if it is only the leaves (see figure 2.3). The healthy cultural value system that supports the Ammatoa community allows Ammatoa residents to protect the surrounding forest ecosystem's stability and easily control all forms of disturbances that occur both from within and from the outside. Similarly, the basic concept of forest environment and ecosystem is the values of traditional wisdom in forest conservation (Disnawati, 2013).

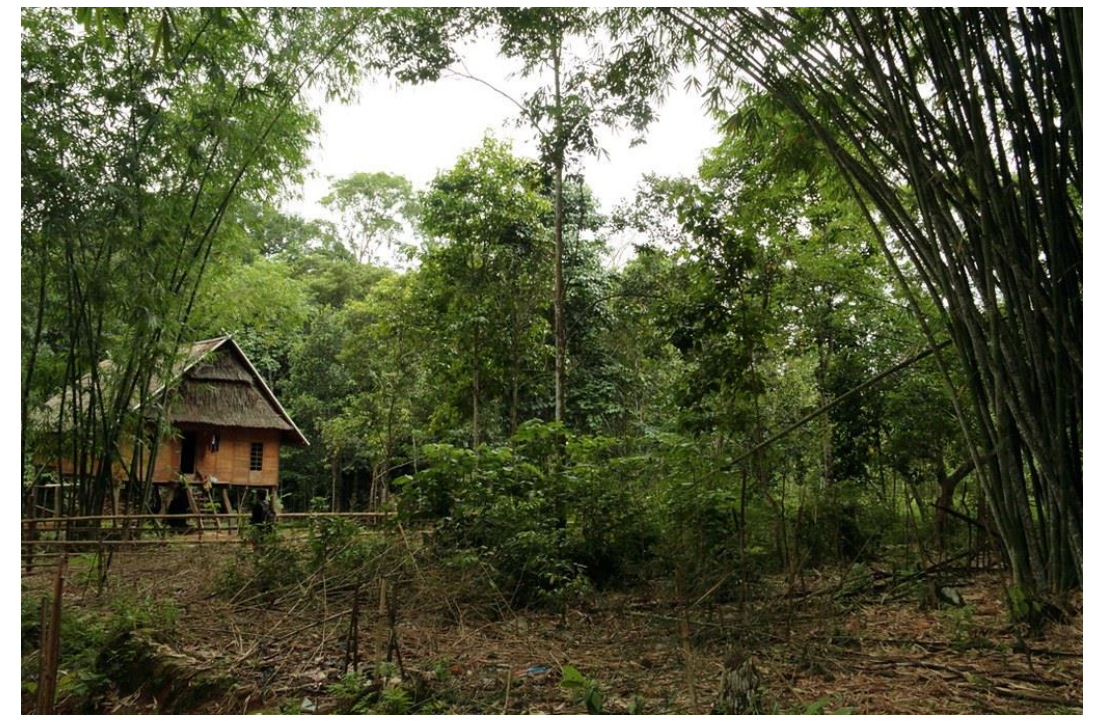

Figure 3 Forest (borong) of Kajang

Resources contained in forest areas can be either wood or non-timber forest products. For example, customary forests include forest rights, that indigenous peoples who inhabit these customary forests have the authority to regulate the designation, function, and utilization of customary forests in their territory (Widowati et. al, 2014). However, customary forests are very vulnerable to customary regulations that prohibit people from cutting down trees or utilizing flora and fauna without permission from tribal chiefs and permitting regulations. To get benefits in the form of wood as indigenous peoples' economic income, thee opportunities are very minimal. Therefore, one of the options for indigenous peoples to still benefit economically from customary forests is to utilize nontimber forest products and environmental services in indigenous areas effectively and sustainably (Nurkhalis et al., 2018).

\section{Conclusion}

Kajang society highly upholds the philosophy of life known as pa'pasang ri Kajang. The Pasang regulates how society relates to the Creator and other communities and regulates how to maintain relationships with nature, in this case, forests. Kajang society also closes itself from technological developments and adheres to the simple principle of life by being grateful for what is. Departing from this, there are various obstacles in developing ecotourism in this area-for example, the absence of supporting infrastructure and minimal telecommunication access. Another problem that arises is the deviation of value that is sometimes done by visitors and stakeholders that there is a trigger for intolerance and discrimination against local culture. This ecotourism empowerment needs to be done by considering various dimensions in direct contact with Kajang local communities' sustainability Community empowerment in building Kajang ecotourism is a process to empower the community. The purpose of community empowerment is to achieve community empowerment which will later change people's lives regarding their social and economic life. Economic empowerment is carried out by further intensifying the role of Indigenous peoples, especially in terms of marketing local products and government support in building infrastructure that helps visitors access this indigenous area. Social empowerment is intended to provide a deeper understanding and avoid miscommunication 
between visitors and indigenous peoples. This is supported by tour guides who clearly understand the perception and culture and apply rules. Then, psychological empowerment is also intended to maintain harmony and comfort between visitors and local communities by implementing applicable rules. Political empowerment is the key to the development of ecotourism in Kajang because the Government and various interested stakeholders are emphasized to decide on various regulations in direct contact with the sustainability of indigenous and natural life, a vital object for the surrounding community. Environmental empowerment is embodied by strengthening the implementation of tidal values in the care of nature, mostly customary forests that are a source of livelihood and ritual media for indigenous peoples. Empowerment carried out by prioritizing these five aspects will build Kajang as an ecotourism destination that copies favorable and inseparable from implementing the rules that apply in pasang.

This research contributes to the government and all stakeholders in building Kajang's ecotourism better by considering local communities and making them a significant force in ecotourism development. Besides, there are scientific contributions in the form of a description of the life of the Kajang ethnic community, which is unique from other indigenous communities, and the development of ecotourism by empowering local communities and implementing traditional values to maintain the balance of human life with nature. The weakness of this study and a suggestion for further research is the need to measure the wheel of empowerment belonging to Mendoza-Ramos \& Prideaux (2018).

\section{References}

Abdullah, A. M., Cangara, H., \& Tang, M. (2014). Komunitas Tradisional Kajang Di Tengah Transformasi Komunikasi dan Informasi. Jurnal Komunikasi KAREBA, 3(2), 103-111.

Asmin, F. (2018). Ekowisata dan Pembangunan Berkelanjutan : Dimulai dari Konsep Sederhana. Bandung: Alfabeta Press. Badewi, M. H. (2018). Etika lingkungan dalam pasang ri kajang pada masyarakat adat Kajang. Jurnal Citizenship: Media Publikasi Pendidikan Pancasila Dan Kewarganegaraan, 1(2), 66-75.

Blamey, R. K. (2001). Principles of Ecotourism. The Encyclopedia of Ecotourism, 32(2), 5-22.

Burns, P. (2005). Ecotourism planning and policy 'Vaka Pasifika'? Tourism and Hospitality Planning \& Development, 2(3), 155-169. https://doi.org/10.1080/14790530500399168

Cajee, L. (2014). Eco-Cultural Tourism: A Tool for Environmental, Cultural and Economic Sustainability (A Case Study of Darap Village, West Sikkim). SHS Web of Conferences, 12(9), 01029. https://doi.org/10.1051/shsconf/20141201029

Ceylan, \& Güven, Ö. Z. (2010). Review: Evaluation of Tourism Management and Ecotourism. Journal of Applied Sciences Research, 6(12), 1943-1952.

Coria, J., \& Calfucura, E. (2012). Ecotourism and the development of indigenous communities: The good, the bad, and the ugly. Ecological Economics, 73(489), 47-55. https://doi.org/10.1016/j.ecolecon.2011.10.024

Dassir, M. (2008). Pranata Sosial Sistem Pengelolaan Hutan Masyarakat Adat Kajang. Jurnal Hutan Dan Masyarakat, $3(2), 135-147$.

Disnawati, D. (2013). Penerapan Prinsip Hidup Kamase-Masea Masyarakat Adat Ammatoa Kajang, Bulukumba Sulawesi Selatan Dalam Pengelolaan Sumber Daya Alam. Sabda: Jurnal Kajian Kebudayaan, 8(1), 83. https://doi.org/10.14710/sabda.v8i1.13257

Eagles, P. F. (2003). International Trends in Park Tourism: The Emerging Role of Finance. The George Wright Forum, 20(1), 25-57.

Embas, A. R. (2017). Analisis Sistem Pemerintahan Desa Adat Ammatoa Dalam Pelestarian Lingkungan Hidup Di Kecamatan Kajang, Kabupaten Bulukumba. Universitas Hasanuddin.

Erwin. (2013). Development Strategy Of Ecotourism Forest Area With Special Destination In Malili, East Luwu Regency, South Sulawesi Province. Jurnal Ilmu Kehutanan, 7(3), 228-245.

Fennell, D. A. (2008). Ecotourism and the Myth of Indigenous Stewardship. Journal of Sustainable Tourism, 16(2), 129-149. https://doi.org/10.2167/jost736.0

Figgis, P. J. (1999). Thenational issues in protected area policy in Australia. Oxford: Butterworth-Heinemann.

Flamin, A., \& Asnaryati. (2013). Potensi Ekowisata Dan Strategi Pengembangan Tahura Nipa-Nipa, Kota Kendari, Sulawesi Tenggara. Jurnal Penelitian Kehutanan Wallacea, 2(2), 154. https://doi.org/10.18330/jwallacea.2013.vol2iss2pp154-168

Gunter, U., \& Ceddia, M. G. (2020). Can Indigenous and Community-Based Ecotourism Serve as a Catalyst for Land Sparing in Latin America? Journal of Travel Research, (Sepsial Issue), 004728752094968. https://doi.org/10.1177/0047287520949687 
Hafid, A. (2013). Sistem Kepercayaan Pada Komunitas Adat Kajang Desa Tanah Towa Kecamatan Kajang Kabupaten Bulukumba. Patanjala: Jurnal Penelitian Sejarah Dan Budaya, 5(1), 1-19. https://doi.org/10.30959/patanjala.v5i1.150

Hall, C. M. (2005). Tourism: Rethinking The Social Science of Mobility. Harlow: Pearson Education.

Henry, J. (2015). Aspek Hukum Perlindungan Hutan Dan Masyarakat Adat Terhadap Pertambangan Batu Bara Di Kampung Tukul Kecamatan Tering Kabupaten Kutai Barat Kalimantan Timur. Jurnal Hukum Pertanahan Dan Lingkungan Hidup, 3(1), 24-38.

Heryanti. (2008). Konsep Islam Dalam Pasang Ri Kajang Sebagai Suatu Kearifan Lokal Tradisional Dalam Sistem Bermukim. Jurnal Kebudayaan Masyarakat, 4(1), 98-109.

Hijjang, P. (2014). Pasang dan Kepemimpinan Ammatoa: Memahami Kembali Sistem Kepemimpinan Tradisional Masyarakat Adat dalam Pengelolaan Sumberdaya Hutan di Kajang Sulawesi Selatan. Antropologi Indonesia, 29(3), 255-268. https://doi.org/10.7454/ai.v29i3.3545

Husain, S. B., \& Kinasih, S. E. (2010). Pasang sebagai Modal Sosial Pengelolaan Hutan pada Masyarakat Adat Ammatowa. Masyarakat, Kebudayaan Dan Politik, 23(3), 229-235.

Ikbal, M. (2018). Pendidikan Formal Masyarakat Adat Kajang. Jurnal Pattingalloang:Pemikiran Pendidikan Dan Penelitian Kesejarahan, 5(3), 30-38.

Islam, F., \& Carlsen, J. (2016). Indigenous communities, tourism development and extreme poverty alleviation in rural Bangladesh. Tourism Economics, 22(3), 645-654. https://doi.org/10.5367/te.2014.0456

Jennings, H. (2017). Indigenous Peoples $\mathcal{E}$ Tourism. London. Retrieved from https://www.tourismconcern.org.uk/wp-content/uploads/2016/02/Indigenous-Peoples-Tourism-1.pdf

Johnston, A. (2000). Indigenous Peoples and Ecotourism: Bringing Indigenous Knowledge and Rights into the Sustainability Equation. Tourism Recreation Research, 25(2), 89-96. https://doi.org/10.1080/02508281.2000.11014914

Lembaga Ilmu Pengetahuan Indonesia. (2013). Pedoman Fasilitator Untuk Pembangunan Ekowisata. Jakarta: LIPI Press.

Levy, S. E., \& Hawkins, D. . (2009). Peace Through Tourism: Commerce Based Principles and Practices. Journal of Business Ethics, 89(4), 569-585. https://doi.org/10.1007/s10551-010-0408-2

Mendoza-Ramos, A., \& Prideaux, B. (2018). Assessing ecotourism in an Indigenous community: using, testing and proving the wheel of empowerment framework as a measurement tool. Journal of Sustainable Tourism, 26(2), 277-291. https://doi.org/10.1080/09669582.2017.1347176

Miles, M. B., \& Huberman, A. M. (1994). Qualitative Data Analysis. Thousand Oaks, CA: Sage.

Miller, K. L. (2008). Evaluating The Design and Management of Community-based Ecotourism Projects in Guatemala. Missoula, US: University of Montana.

Muhdar, M. Z., \& Jasmaniar. (2006). Studi Perbandingan A'borong (Musyawarah) Masyarakat Hukum Adat Kajang Dihubungkan Dengan PERMA Nomor: 1 Tahun 2016 Tentang Mediasi. Petitium, 8(1), 57-70.

Nash, R. (1970). The American Invention of National Parks. American Quarterly, 22(3), $726-735$. https://doi.org/10.2307/2711623

Nazarullail, F., \& Desyanty, E. S. (2017). Pemberdayaan Masyarakat Melalui Program Ekowisata “Lepen Adventure". Jurnal Pendidikan: Teori, Penelitian, Dan Pengembangan, 2(8), 1071-1076.

Nurkhalis, N., Arief, H., \& Sunarminto, T. (2018). Analisis Stakeholders Dalam Pengembangan Ekowisata di Hutan Adat Ammatoa Kajang Sulawesi Selatan. Jurnal Pariwisata, 5(2), 107-119. https://doi.org/10.31311/par.v5i2.3811

Ramos, A. M., \& Prideaux, B. (2014). Indigenous ecotourism in the Mayan rainforest of Palenque: empowerment issues in sustainable development. Journal of Sustainable Tourism, 22(3), 461-479. https://doi.org/10.1080/09669582.2013.828730

Rusdiansyah. (2019). Sumur dan Budaya Suku Kajang; Kearifan Lokal Suku Kajang. Jurnal Commercium: Kajian Masyarakat Kontemporer, 2(2), 29-35.

Sambou, O., Riniwati, H., \& Fanani, Z. (2019). Socio-economic and Environmental Sustainability of Ecotourism Implementation: A Study in Ubud Monkey Forest-Bali, Indonesia. Journal of Indonesian Tourism and Development Studies, 7(3), 200-204. https://doi.org/10.21776/ub.jitode.2019.007.03.09

Sharon, S. S., \& Paranoan, S. (2020). Refleksi Rumah Adat Ammatoa Dalam Akuntabilitas Organisasi. Jurnal Akuntansi Multiparadigma, 11(1), 59-76. https://doi.org/10.21776/ub.jamal.2020.11.1.04

Sinapoy, M. S. (2018). Kearifan Lokal Masyarakat Adat Suku Moronene dalam Perlindungan dan Pengelolaan Lingkungan Hidup. Halu Oleo Law Review, 2(2), 513. https://doi.org/10.33561/holrev.v2i2.4513

Sudirman. (2017). Proses Interaksi Sosial Komunitas Adat Kajang Di Desa Tana Toa Kecamatan Kajang Kabupaten Bulukumba. UIN Alauddin Makassar.

Sugiyanto, C., \& Winardi, R. D. (2019). Strategi Penelitian Etnografi. Yogyakarta. 
Syarif, E. (2018). Representasi Aturan Adat Dalam Pengelolaan Hutan Masyarakat Adat Ammatoa Sulawesi Selatan. Jurnal Environmental Science, 1(1), 40-52. https://doi.org/10.35580/jes.v1i1.7426

Syukur, A., Tao, A., Prameswari, A., Jauhari, A., Kiki, A., Fatrysa, C., ... Javle, T. (2015). Hutan Untuk Kesejahteraan : Cerita dari Lapangan. Jakarta: The Royal Norwegian Embassy.

Usbar, N., Mahbub, A. S., \& Makkarennu. (2019). Local Knowledge of Kajang Indigenous Peoples in Utilizing Forest Plants for Treatment). Jurnal SMART (Studi Masyarakat, Religi, Dan Tradisi), 2(1), 92-103. https://doi.org/10.1088/1755-1315/270/1/012026

Utaya, S., \& Susilo, S. (2015). Kearifan Lokal Masyarakat Adat Dalam Pelestarian Hutan Sebagai Sumber Belajar Geografi. Jurnal Pendidikan Humaniora, 3(3), 202-208.

Wijaya, H. (2018). Nilai-Nilai Pasang ri Kajang pada Adat Ammatoa Sebagai Local Wisdom Untuk Mewujudkan Karakter Peduli Lingkungan Dalam Pendidikan Masa Kini. Jurist-Diction, 2(1), 28-39.

Windiani, \& Nurul, F. (2016). Menggunakan metode etnografi dalam penelitian sosial. Dimensi Jurnal Sosiologi, 9(2), 87-92.

Zeppel, H. (2003). Sharing the country: ecotourism policy and indigenous peoples in Australia. In Ecotourism policy and planning (pp. 55-76). Wallingford: CABI. https://doi.org/10.1079/9780851996097.0055

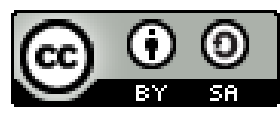

(C) 2021 by the authors. Submitted for possible open access publication under the terms and conditions of the Creative Commons Attribution (CC BY SA) license (https://creativecommons.org/licenses/by-sa/3.0/). 
This page is intentionally left blank 